\title{
DESIGN, SYNTHESIS AND MOLECULAR MODELING STUDY OF 1,2,4-TRIAZOLE CARBOHYDRAZIDE DERIVATIVES WITH POTENTIAL ANTIMICROBIAL AND ANTI-INFLAMMATORY ACTIVITIES
}

Nawal A. El-Koussi

Department of Medicinal Chemistry, Faculty of Pharmacy, Assiut University, Assiut, 71526, Egypt

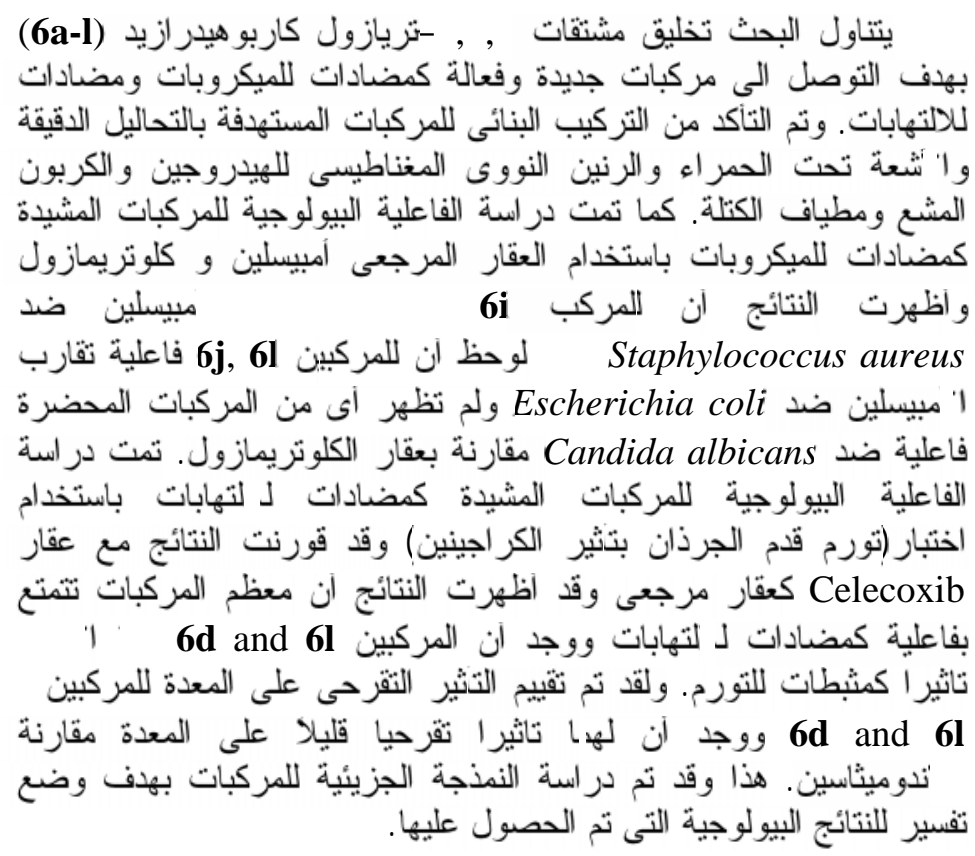

The present investigation is concerned with the synthesis of 1,2,4-triazole carbohydrazide derivatives (6a-1) with the objective of discovering novel and potent antimicrobial and antiinflammatory agents.

The chemical structures of the target compounds were elucidated by elemental analyses, IR, ${ }^{1} \mathrm{H}-\mathrm{NMR},{ }^{13} \mathrm{C}-\mathrm{NMR}$ and mass spectral data. The antimicrobial activity of the target compounds were evaluated and compared with ampicillin trihydrate and clotrimazole as references compounds. The results showed that 
compound $\mathbf{6 i}$ revealed a similiar level of activity as ampicillin against Staphylococcus aureus, while compounds $\mathbf{6 j}$ and $\mathbf{6 l}$ exhibited comparable activity against Escherichia coli. All compounds were less active against Candida albicans when compared with clotrimazole. The results of anti-inflammatory showed that compounds $\mathbf{6 d}, \mathbf{6} \mathbf{1}$ possessed higher anti-inflammatory activity than celecoxib in carageenan-induced rat paw edema test with low gastric ulcerogenicity compared with indomethacin. Molecular modeling studies were performed in order to rationalize the obtained biological results.

\section{INTRODUCTION}

It has been reported that many compounds having 1,2,4- triazole skeleton possessed interesting biological activities such as antibacterial $^{1-4}$, antifungal ${ }^{5-7}$, analgesic $^{8}$ and anti-inflammatory ${ }^{8-17}$.

Non steroidal anti-inflammatory drugs (NSAIDs) are among the most widely used therapeutics, primarily for treatment of pain and inflammation in arthritis for decades. NSAIDs reduce pain and swelling associated with arthritis by blocking the metabolism of arachidonic acid by cycloxygenase enzyme COX thereby the production of prostaglandin ${ }^{18}$. Prostaglandins are cytoprotective, administration of NSAIDs in long term may lead to GI ulcers, bleeding and renal disorders.

In the present investigation it seemed of interest to synthesize 5phenyl-1-(3-pyridyl)1H-1,2,4-

triazole-3-carboxylic acid derivatives and study the effect of cyclization on anti-inflammatory activity.

\section{EXPERIMENTAL}

\section{Chemistry}

Melting points were determined on Electrothermal Melting Point Apparatus and are uncorrected. Elemental microanalyses were performed on Perkin-Elmer, 240 Elemental Analyzer, at the central laboratory, Assiut University. TLC was carried out using silica gel 60 $\mathrm{F}_{254}$ precoated (E. Merck, Germany) and were visualized using UV lamp at $254 \mathrm{~nm}$. IR spectra were recorded as $\mathrm{KBr}$ disks on a 470 Shimadzu IR Spectrophotometer at the Faculty of Pharmacy, Assiut University. ${ }^{1} \mathrm{H}-$ NMR spectra were recorded on a JEOL JNM-AL 300 FT NMR system. Chemical shifts are reported in parts per million $(\delta)$ relative to tetramethylsilane (TMS) as internal standard. DMSO- $\mathrm{d}_{6}$ was used as solvent. ${ }^{13} \mathrm{C}-\mathrm{NMR}$ spectra were recorded on JEOL-JNM-EX 300, $75.45 \mathrm{MHz}$. Electrospray ionizationMass spectra (ESI-MS) were determined on a Finnigan mass spectrometer. 
4-(3-Pyridyl)-hydrazono-2-phenyl-

2-oxazolin-5-one $3^{14}$

(Yield 70\%).

5-Phenyl-1-(3-pyridyl)-1,2,4-

triazole-3-carboxylic acid

hydrazide $4^{14}$

Yield 54\%, m.p. $140-142^{\circ} \mathrm{C}$.

$\mathrm{N}^{4}$-Substituted 5-phenyl-1-(3-pyridyl)-1,2,4-triazole-3-carboxylic acid thiosemicarbazide 5a-f ${ }^{14}$

To a suspension of 5-phenyl-1-(3pyridyl)-1,2,4-triazole-3-carboxylic acid hydrazide 4 (2.8 g, $0.01 \mathrm{~mol})$ in ethanol $(40 \mathrm{ml})$; a solution of the appropriate isothiocyanate $(0.01 \mathrm{~mol})$ in ethanol $(10 \mathrm{ml})$ was added. The mixture was refluxed for 2 hrs. The reaction mixture was cooled and the separated solid was filtered, washed with ethanol and crystallized from appropriate solvent.

\section{N'-(3-Substituted-4-phenyl $(p$ -} chlorophenyl)thiazol-2(3H)-ylidene)-5-phenyl-1-(pyridin-3-yl)-1H1,2,4-triazole-3-carbohydrazide 6a-l

A mixture of $5(0.002 \mathrm{~mol})$, phenacyl bromide or $p$-chlorophenacyl bromide $(0.002 \mathrm{~mol})$ and freshly fused sodium acetate $(0.25 \mathrm{~g}$, $0.003 \mathrm{~mol})$ in ethanol $(25 \mathrm{ml})$ was heated under reflux for 4-6 hrs. The solvent was evaporated off and the reaction product was allowed to cool. The separated product was filtered off, washed with water and crystallized from a suitable solvent. The physical data of the synthesized compounds 6a-1 are shown in Table 1.
N'-(3-Methyl-4-phenylthiazol-2

(3H)-ylidene)-5-phenyl-1-(pyridin3-yl)-1H-1,2,4-triazole-3-carbohydrazide 6a

IR $\left(\mathrm{KBr}, \mathrm{cm}^{-1}\right): 3410(\mathrm{NH}), 1678$ (CO), $1613(\mathrm{C}=\mathrm{N}), 1348(\mathrm{CS})$.

${ }^{1} \mathrm{H}-\mathrm{NMR} \quad\left(\right.$ DMSO-d $\left.\mathrm{d}_{6}\right) \quad \delta \quad(\mathrm{ppm})$ : 11.15-10.90 (1H, br.s, $\mathrm{CONH}$, exchangeable $), \quad 9.00-8.80 \quad(2 \mathrm{H}, \mathrm{m}$, pyr. $\left.\mathrm{H}_{2,6}\right), 8.35-8.00\left(2 \mathrm{H}, \mathrm{m}\right.$, pyr. $\left.\mathrm{H}_{4,5}\right)$, 8.00-7.50 (10H, m, ArH), 6.50-6.30 (1H, s, C5-H of thiazoline), 3.60-3.30 $\left(3 \mathrm{H}, \mathrm{s}, \mathrm{CH}_{3}\right)$.

Electron impact mass spectrum (EI-MS): $\mathrm{m} / \mathrm{z} 454.3\left(\mathrm{M}^{+}+1\right), 476.2$ $\left(\mathrm{M}^{+}+\mathrm{Na}\right)$ was consistent with the expected structure.

N'-(3-Methyl-4-p-chlorophenylthiazol-2(3H)-ylidene)-5-phenyl-1(pyridin-3-yl)-1H-1,2,4-triazole-3carbohydrazide $6 \mathrm{~b}$

IR $\left(\mathrm{KBr}, \mathrm{cm}^{-1}\right) ; 3410(\mathrm{NH}), 1678$ (CO), $1610(\mathrm{C}=\mathrm{N}), 1394(\mathrm{CS})$.

${ }^{1} \mathrm{H}-\mathrm{NMR} \quad\left(\mathrm{DMSO}-\mathrm{d}_{6}\right) \quad \delta \quad(\mathrm{ppm})$ 11.15-10.95 (1H, br.s, CONH, exchangeable $), 9.05-8.80 \quad(2 \mathrm{H}, \mathrm{m}$, pyr. $\left.\mathrm{H}_{2,6}\right), 8.35-8.00\left(2 \mathrm{H}, \mathrm{m}\right.$, pyr. $\left.\mathrm{H}_{4,5}\right)$, 8.00-7.50 (9H, m, ArH), 6.65-6.45 $(1 \mathrm{H}, \quad \mathrm{s}, \mathrm{C} 5-\mathrm{H}$ of thiazoline $), 3.60-$ $3.40\left(3 \mathrm{H}, \mathrm{s}, \mathrm{CH}_{3}\right) .{ }^{13} \mathrm{C}-\mathrm{NMR}$ (DMSO$\left.\mathrm{d}_{6}\right) \delta$ (ppm): 168.16 (CO), 156.47, $155.04, \quad 154.52,146.41,139.18$, $134.26,133.95,125.0$ (quaternary cabons), $150.32, \quad 150.0, \quad 133.60$, $133.55, \quad 130.42, \quad 129.23, \quad 129.0$, $128.83, \quad 128.69, \quad 127.50, \quad 127.60$, 126.69, 124.20, $97.69(\mathrm{CH}=), 33.14$ $\left(\mathrm{CH}_{3}\right)$. Electron impact mass spectrum (EI-MS): $\quad \mathrm{m} / \mathrm{z} \quad 488.11$ $\left(\mathrm{M}^{+}+1\right), 510.31\left(\mathrm{M}^{+}+\mathrm{Na}\right)$. 
Table 1: Physical data of the target compounds (6a-l).

\begin{tabular}{|c|c|c|c|c|c|c|c|c|}
\hline \multirow{2}{*}{$\begin{array}{l}\text { Compd. } \\
\text { No. }\end{array}$} & \multirow{2}{*}{$\mathrm{R}$} & \multirow{2}{*}{ R1 } & \multirow{2}{*}{$\begin{array}{c}\text { m.p. }\left[{ }^{\circ} \mathrm{C}\right] \\
\text { Solvent } \\
\text { of crystal. }\end{array}$} & \multirow{2}{*}{$\begin{array}{c}\text { Yield } \\
{[\%]}\end{array}$} & \multirow{2}{*}{$\begin{array}{l}\text { Molecular } \\
\text { formula / Mol.Wt }\end{array}$} & \multicolumn{3}{|c|}{ Microanalyses } \\
\hline & & & & & & $\mathrm{C}$ & $\mathrm{H}$ & $\mathrm{N}$ \\
\hline $6 a$ & $\mathrm{CH}_{3}$ & $\mathrm{H}$ & $\begin{array}{c}227-8 \\
\text { aq.DMF }\end{array}$ & 84 & $\begin{array}{c}\mathrm{C}_{24} \mathrm{H}_{19} \mathrm{~N}_{7} \mathrm{OS} \\
453.52\end{array}$ & $\begin{array}{l}63.56 \\
63.99 \\
\end{array}$ & $\begin{array}{l}4.22 \\
4.44 \\
\end{array}$ & $\begin{array}{l}21.62 \\
21.31 \\
\end{array}$ \\
\hline $6 b$ & $\mathrm{CH}_{3}$ & $\mathrm{Cl}$ & $\begin{array}{l}216-17 \\
\text { aq.DMF }\end{array}$ & 80 & $\begin{array}{c}\mathrm{C}_{24} \mathrm{H}_{18} \mathrm{ClN}_{7} \mathrm{OS} \\
487.96 \\
\end{array}$ & $\begin{array}{l}59.07 \\
58.94 \\
\end{array}$ & $\begin{array}{l}3.72 \\
3.73 \\
\end{array}$ & $\begin{array}{l}20.09 \\
20.04 \\
\end{array}$ \\
\hline $6 c$ & $\mathrm{C}_{2} \mathrm{H}_{5}$ & $\mathrm{H}$ & $\begin{array}{c}192-3 \\
\text { aq.DMF }\end{array}$ & 83 & $\begin{array}{r}\mathrm{C}_{25} \mathrm{H} \\
46 \\
\end{array}$ & $\begin{array}{l}64.22 \\
64.23 \\
\end{array}$ & $\begin{array}{l}4.53 \\
4.63 \\
\end{array}$ & $\begin{array}{l}20.97 \\
21.23 \\
\end{array}$ \\
\hline 6d & $\mathrm{C}_{2} \mathrm{H}_{5}$ & $\mathrm{Cl}$ & $\begin{array}{c}244-5 \\
\text { aq.DMF }\end{array}$ & 86 & $\begin{array}{r}\mathrm{C}_{25} \mathrm{H}_{20} \\
50 \\
\end{array}$ & $\begin{array}{l}59.82 \\
59.40\end{array}$ & $\begin{array}{l}4.02 \\
3.59 \\
\end{array}$ & $\begin{array}{l}19.53 \\
19.45 \\
\end{array}$ \\
\hline $6 e$ & $\mathrm{C}_{6} \mathrm{H}_{5}$ & $\mathrm{H}$ & $\begin{array}{c}210-12 \\
\text { Methanol }\end{array}$ & 72 & $\begin{array}{r}\mathrm{C}_{29} \mathrm{H}_{21} \\
515 \\
\end{array}$ & $\begin{array}{l}67.56 \\
67.57 \\
\end{array}$ & $\begin{array}{l}4.11 \\
4.32 \\
\end{array}$ & $\begin{array}{l}19.02 \\
19.40 \\
\end{array}$ \\
\hline $6 f$ & $\mathrm{C}_{6} \mathrm{H}_{5}$ & $\mathrm{Cl}$ & $\begin{array}{c}222-3 \\
\text { Methanol }\end{array}$ & 70 & $\begin{array}{c}\mathrm{C}_{29} \mathrm{H}_{20} \mathrm{ClN}_{7} \mathrm{OS} \\
550.03\end{array}$ & $\begin{array}{l}63.33 \\
63.04\end{array}$ & $\begin{array}{l}3.67 \\
3.75\end{array}$ & $\begin{array}{l}17.83 \\
18.50\end{array}$ \\
\hline $6 \mathrm{~g}$ & $p-\mathrm{CH}_{3} \mathrm{C}_{6} \mathrm{H}_{4}$ & $\mathrm{H}$ & $\begin{array}{c}240-1 \\
\text { Methanol }\end{array}$ & 73 & $\begin{array}{c}\mathrm{C}_{30} \mathrm{H}_{23} \mathrm{~N}_{7} \mathrm{OS} \\
529.62\end{array}$ & $\begin{array}{l}68.03 \\
68.41\end{array}$ & $\begin{array}{l}4.38 \\
4.56\end{array}$ & $\begin{array}{l}18.51 \\
18.90 \\
\end{array}$ \\
\hline 6h & $p-\mathrm{CH}_{3} \mathrm{C}_{6} \mathrm{H}_{4}$ & $\mathrm{Cl}$ & $\begin{array}{c}246-7 \\
\text { Methanol } \\
\end{array}$ & 76 & $\begin{array}{c}\mathrm{C}_{30} \mathrm{H}_{22} \mathrm{ClN}_{7} \mathrm{OS} \\
564.06 \\
\end{array}$ & $\begin{array}{l}63.88 \\
64.21 \\
\end{array}$ & $\begin{array}{l}3.93 \\
4.21 \\
\end{array}$ & $\begin{array}{l}17.38 \\
17.63 \\
\end{array}$ \\
\hline $6 \mathbf{i}$ & $p-\mathrm{BrC}_{6} \mathrm{H}_{4}$ & $\mathrm{H}$ & $\begin{array}{c}230-1 \\
\text { aq.DMF }\end{array}$ & 79 & $\begin{array}{c}\mathrm{C}_{29} \mathrm{H}_{20} \mathrm{BrN}_{7} \mathrm{OS} \\
594.49\end{array}$ & $\begin{array}{l}58.59 \\
59.00\end{array}$ & $\begin{array}{l}3.39 \\
3.87\end{array}$ & $\begin{array}{l}16.49 \\
16.75\end{array}$ \\
\hline $\mathbf{6 j}$ & $p-\mathrm{BrC}_{6} \mathrm{H}_{4}$ & $\mathrm{Cl}$ & $\begin{array}{c}228-30 \\
\text { aq.DMF }\end{array}$ & 75 & $\begin{array}{c}\mathrm{C}_{29} \mathrm{H}_{19} \mathrm{BrClN}_{7} \mathrm{OS} \\
628.93\end{array}$ & $\begin{array}{l}55.38 \\
55.68\end{array}$ & $\begin{array}{l}3.04 \\
3.44\end{array}$ & $\begin{array}{l}15.59 \\
15.34\end{array}$ \\
\hline $6 k$ & c-hexyl & $\mathrm{H}$ & $\begin{array}{c}192-3 \\
\text { Methanol }\end{array}$ & 67 & $\begin{array}{c}\mathrm{C}_{29} \mathrm{H}_{27} \mathrm{~N}_{7} \mathrm{OS} \\
521.64\end{array}$ & $\begin{array}{l}66.77 \\
67.00\end{array}$ & $\begin{array}{l}5.22 \\
5.61\end{array}$ & $\begin{array}{l}18.80 \\
19.12\end{array}$ \\
\hline 61 & c-hexyl & $\mathrm{Cl}$ & $\begin{array}{c}241-3 \\
\text { Methanol }\end{array}$ & 65 & $\begin{array}{c}\mathrm{C}_{29} \mathrm{H}_{26} \mathrm{ClN}_{7} \mathrm{OS} \\
556.08\end{array}$ & $\begin{array}{l}62.64 \\
62.79\end{array}$ & $\begin{array}{l}4.71 \\
4.82\end{array}$ & $\begin{array}{l}17.63 \\
17.53 \\
\end{array}$ \\
\hline
\end{tabular}

N`(3-Ethyl-4-phenylthiazol-2(3H)ylidene)-5-phenyl-1-(pyridin-3-yl)1H-1,2,4-triazole-3-carbohydrazide 6c

IR $\left(\mathrm{KBr}, \mathrm{cm}^{-1}\right): 3410(\mathrm{NH}), 1672$ (CO), $1613(\mathrm{C}=\mathrm{N}), 1334$ (CS).

${ }^{1} \mathrm{H}-\mathrm{NMR} \quad\left(\mathrm{DMSO}-\mathrm{d}_{6}\right) \quad \delta \quad(\mathrm{ppm})$ : 11.15-10.85 $(1 \mathrm{H}, \quad$ br.s, $\mathrm{CONH}$, exchangeable), 9.05-8.75 (2H, m, pyr. $\left.\mathrm{H}_{2,6}\right), 8.25-7.95\left(2 \mathrm{H}, \mathrm{m}\right.$, pyr. $\left.\mathrm{H}_{4,5}\right)$, 7.90-7.30 (10H,m, ArH), 6.45-6.25 $(1 \mathrm{H}, \quad \mathrm{s}, \quad \mathrm{C} 5-\mathrm{H}$ of thiazoline $), 4.10-$ $3.60\left(2 \mathrm{H}, \mathrm{q}, \mathrm{CH}_{2} \mathrm{CH}_{3}\right), 1.60-0.90(3 \mathrm{H}$,

$\mathrm{t}, \mathrm{CH}_{2} \mathrm{CH}_{3}$ ).

Electron impact mass spectrum (EI-MS): $\mathrm{m} / \mathrm{z} 467.9\left(\mathrm{M}^{+}+1\right), 490.01$ $\left(\mathrm{M}^{+}+\mathrm{Na}\right)$.

\section{$\mathbf{N}^{`}$-(3-Ethyl-4-p-chlorophenyl-}

thiazol-2(3H)-ylidene)-5-phenyl-1(pyridin-3-yl)-1H-1,2,4-triazole-3carbohydrazide 6d

IR $\left(\mathrm{KBr}, \mathrm{cm}^{-1}\right)$ : $3410(\mathrm{NH}), 1678$ (CO), $1613(\mathrm{C}=\mathrm{N}), 1365(\mathrm{CS})$. 
${ }^{1} \mathrm{H}-\mathrm{NMR} \quad\left(\mathrm{DMSO}-\mathrm{d}_{6}\right) \quad \delta \quad(\mathrm{ppm})$ : 11.10-10.90 (1H, br.s, CONH, exchangeable), 9.10-8.75 (2H, m, pyr. $\left.\mathrm{H}_{2,6}\right), 8.35-7.95\left(2 \mathrm{H}, \mathrm{m}\right.$, pyr. $\left.\mathrm{H}_{4,5}\right)$, 7.90-7.40 (9H, m, ArH), 6.55-6.30 $(1 \mathrm{H}, \quad \mathrm{s}, \mathrm{C} 5-\mathrm{H}$ of thiazoline), 4.10$3.60\left(2 \mathrm{H}, \mathrm{q}, \mathrm{CH}_{2} \mathrm{CH}_{3}\right), 1.40-0.95(3 \mathrm{H}$, $\mathrm{t}, \mathrm{CH}_{2} \mathrm{CH}_{3}$ ).

Electron impact mass spectrum (EI-MS): $\mathrm{m} / \mathrm{z} 502.11\left(\mathrm{M}^{+}+1\right), 524.21$ $\left(\mathrm{M}^{+}+\mathrm{Na}\right)$.

$\mathbf{N}^{`}$-(3-Phenyl-4-phenylthiazol-2(3H)ylidene)-5-phenyl-1-(pyridin-3-yl)1H-1,2,4-triazole-3-carbohydrazide 6e

IR $\left(\mathrm{KBr}, \mathrm{cm}^{-1}\right): 3410(\mathrm{NH}), 1673$ $(\mathrm{CO}), 1358(\mathrm{C}=\mathrm{N}), 1306(\mathrm{CS})$.

${ }^{1} \mathrm{H}-\mathrm{NMR} \quad\left(\mathrm{DMSO}_{\mathrm{d}} \mathrm{d}_{6}\right) \delta$ (ppm): $10.90(1 \mathrm{H}$, br.s, CONH, exchangeable), $8.90-8.60$ (2H, m, pyr. $\left.\mathrm{H}_{2,6}\right)$, 8.20-7.90 (2H, m, pyr. $\left.\mathrm{H}_{4.5}\right), 7.59-7.34$ $(15 \mathrm{H}, \mathrm{m}, \mathrm{ArH}), 6.90(1 \mathrm{H}, \mathrm{s}, \mathrm{C} 5-\mathrm{H}$ of thiazoline).

N`-(3-Phenyl-4-p-chlorophenylthiazol-2(3H)-ylidene)-5-phenyl-1(pyridin-3-yl) 1H-1,2,4-triazole-3carbohydrazide $6 \mathbf{f}$

IR $\left(\mathrm{KBr}, \mathrm{cm}^{-1}\right): 3410(\mathrm{NH}), 1678$ (CO), $1358(\mathrm{C}=\mathrm{N}), 1313(\mathrm{CS})$.

${ }^{1} \mathrm{H}-\mathrm{NMR}$ (DMSO-d $\mathrm{d}_{6}$ ) $\delta$ (ppm): $10.97(1 \mathrm{H}$, br.s, CONH, exchangeable), $8.70-8.55$ (2H, m, pyr. $\left.\mathrm{H}_{2,6}\right)$, 8.30-7.90 (2H, m, pyr. $\left.\mathrm{H}_{4,5}\right), 7.34-7.59$ $(14 \mathrm{H}, \mathrm{m}, \mathrm{ArH}), 6.90(1 \mathrm{H}, \mathrm{s}, \mathrm{C} 5-\mathrm{H}$ of thiazoline).

N`(3-p-Methylphenyl-4-phenylthiazol-2(3H)-ylidene)-5-phenyl-1(pyridin-3-yl)-1H-1,2,4-triazole-3carbohydrazide $6 \mathrm{~g}$

IR $\left(\mathrm{KBr}, \mathrm{cm}^{-1}\right): 3410(\mathrm{NH}), 1675$ (CO), $1358(\mathrm{C}=\mathrm{N}), 1313$ (CS).
${ }^{1} \mathrm{H}-\mathrm{NMR} \quad\left(\right.$ DMSO-d $\left.\mathrm{d}_{6}\right) \quad \delta \quad(\mathrm{ppm})$ 10.97 (1H, br.s, CONH, exchangeable), $8.70-8.50\left(2 \mathrm{H}, \mathrm{m}\right.$, pyr. $\left.\mathrm{H}_{2,6}\right)$, 8.30-8.00 (2H, m, pyr. $\left.\mathrm{H}_{4.5}\right), 7.90-7.10$ $(14 \mathrm{H}, \mathrm{m}, \mathrm{ArH}), 6.90(1 \mathrm{H}, \mathrm{s}, \mathrm{C} 5-\mathrm{H}$ of thiazoline), $2.30\left(3 \mathrm{H}, \mathrm{s}, \mathrm{CH}_{3}\right)$.

N'-(3-p-Methylphenyl-4-p-chlorophenylthiazol-2(3H)-ylidene)-5phenyl-1-(pyridin-3-yl)-1H-1,2,4triazole-3-carbohydrazide $6 \mathrm{~h}$

IR $\left(\mathrm{KBr}, \mathrm{cm}^{-1}\right): 3410(\mathrm{NH}), 1675$ (CO), $1358(\mathrm{C}=\mathrm{N}), 1313$ (CS).

${ }^{1} \mathrm{H}-\mathrm{NMR} \quad\left(\mathrm{DMSO}-\mathrm{d}_{6}\right) \quad \delta \quad(\mathrm{ppm})$ 10.97 (1H, br.s, CONH, exchangeable), 8.80-8.50 (2H, m, pyr. $\left.\mathrm{H}_{2,6}\right)$, 8.30-8.00 (2H, m, pyr. $\left.\mathrm{H}_{4,5}\right), 7.90-7.25$ $(13 \mathrm{H}, \mathrm{m}, \mathrm{ArH}), 6.90(1 \mathrm{H}, \mathrm{s}, \mathrm{C} 5-\mathrm{H}$ of thiazoline), $2.30\left(3 \mathrm{H}, \mathrm{s}, \mathrm{CH}_{3}\right)$.

N`-(3-p-Bromophenyl-4-phenylthiazol-2(3H)-ylidene)-5-phenyl-1(pyridin-3-yl)-1H-1,2,4-triazole-3carbohydrazide $6 \mathbf{i}$

IR $\left(\mathrm{KBr}, \mathrm{cm}^{-1}\right): 3410(\mathrm{NH}), 1675$ (CO), $1358(\mathrm{C}=\mathrm{N}), 1313$ (CS).

${ }^{1} \mathrm{H}-\mathrm{NMR}$ (DMSO-d $\left.\mathrm{d}_{6}\right) \quad \delta(\mathrm{ppm})$ 11.30 (1H, br.s., $\mathrm{CONH}$, exchangeable $)$, 8.90-8.60 (2H, m, pyr. $\left.\mathrm{H}_{2,6}\right)$, 8.30-8.00 (2H, m, pyr. $\left.\mathrm{H}_{4,5}\right), 7.90-7.50$ $(14 \mathrm{H}, \mathrm{m}, \mathrm{ArH}), 6.90((1 \mathrm{H}, \mathrm{s}, \mathrm{C} 5-\mathrm{H}$ of thiazoline).

N`(3-p-Bromophenyl-4-p-chlorophenylthiazol-2(3H)-ylidene)-5phenyl-1-(pyridin-3-yl)-1H-1,2,4triazole-3-carbohydrazide $\mathbf{6 j}$

IR $\left(\mathrm{KBr}, \mathrm{cm}^{-1}\right): 3410(\mathrm{NH}), 1675$ (CO), $1358(\mathrm{C}=\mathrm{N}), 1313(\mathrm{CS})$.

${ }^{1} \mathrm{H}-\mathrm{NMR} \quad\left(\mathrm{DMSO}_{-} \mathrm{d}_{6}\right) \quad \delta$ (ppm): $11.35(1 \mathrm{H}$, br.s., $\mathrm{CONH}$, exchangeable), 9.05-8.65 (2H, m, pyr. $\left.\mathrm{H}_{2,6}\right)$, 
8.40-8.00 (2H, m, pyr. $\left.\mathrm{H}_{4.5}\right), 7.90-7.60$ $(13 \mathrm{H}, \mathrm{m}, \mathrm{ArH}), 6.90(1 \mathrm{H}, \mathrm{s}, \mathrm{C} 5-\mathrm{H}$ of thiazoline).

\section{N'-(3-Cyclohexyl-4-phenylthiazol- 2(3H)-ylidene)-5-phenyl-1-(pyridin- 3-yl)-1H-1,2,4-triazole-3-carbo- hydrazide $6 \mathrm{k}$}

IR $\left(\mathrm{KBr}, \mathrm{cm}^{-1}\right): 3410(\mathrm{NH}), 1675$ (CO), $1358(\mathrm{C}=\mathrm{N}), 1313$ (CS).

${ }^{1} \mathrm{H}-\mathrm{NMR} \quad\left(\mathrm{DMSO}-\mathrm{d}_{6}\right) \quad \delta \quad(\mathrm{ppm})$ : $10.85(1 \mathrm{H}, \mathrm{s}, \mathrm{CONH}$, exchangeable), 8.80-8.60 (2H, m, pyr. $\left.\mathrm{H}_{2,6}\right), 8.30-8.00$ $\left(2 \mathrm{H}, \mathrm{m}\right.$, pyr. $\left.\mathrm{H}_{4,5}\right), 7.90-7.30(10 \mathrm{H}, \mathrm{m}$, $\mathrm{ArH}), \quad 6.85 \quad(1 \mathrm{H}, \quad \mathrm{s}, \quad \mathrm{C} 5-\mathrm{H} \quad$ of thiazoline), 3.00-2.45 (1H, hump, c.hexyl), 2.10-0.90 (10H, m, c.hexyl).

$\mathrm{N}^{\prime}$-(3-Cyclohexyl-4-p-chlorophenylthiazol-2(3H)-ylidene)-5-phenyl-1(pyridin-3-yl)-1H-1,2,4-triazole-3carbohydrazide 61

IR $\left(\mathrm{KBr}, \mathrm{cm}^{-1}\right): 3410(\mathrm{NH}), 1675$ (CO), $1358(\mathrm{C}=\mathrm{N}), 1313$ (CS).

${ }^{1} \mathrm{H}-\mathrm{NMR} \quad\left(\mathrm{DMSO}-\mathrm{d}_{6}\right) \quad \delta$ (ppm): $10.85(1 \mathrm{H}, \mathrm{s}, \mathrm{CONH}$, exchangeable), 8.80-8.60 (2H, m, pyr. $\left.\mathrm{H}_{2,6}\right), 8.30-8.00$ $\left(2 \mathrm{H}, \mathrm{m}\right.$, pyr. $\left.\mathrm{H}_{4,5}\right), 7.90-7.30(9 \mathrm{H}, \mathrm{m}$, $\mathrm{ArH}), \quad 6.90 \quad(1 \mathrm{H}, \quad \mathrm{s}, \quad \mathrm{C} 5-\mathrm{H}$ of thiazoline), 3.20-2.55 (1H, hump, c.hexyl), 2.20-1.10 (10H, m, c.hexyl). Electron impact mass spectrum (EIMS): $\mathrm{m} / \mathrm{z} \quad 556.01 \quad\left(\mathrm{M}^{+}+1\right), \quad 578.01$ $\left(\mathrm{M}^{+}+\mathrm{Na}\right)$.

\section{Antimicrobial activity}

Microbiological screening was carried out at Mycological Center Assiut University. The microdilution susceptibility test in Müller-Hinton Broth (Oxoid) and Sabouraud Liquid Medium (Oxoid) were used for the determination of antibacterial and antifungal activities ${ }^{19}$. The utilized test organisms were: Escherichia coli (E. coli) ATCC 25922 as an example of Gram-negative bacteria, Staphylococcus aureus (S. aureus) ATCC 19433 as an example of Grampositive bacteria and Candida albicans $(C$. albicans) as yeast-like fungi. Ampicillin trihydrate and clotrimazole were used as standard antibacterial and antifungal agents, respectively. Solutions of the test compounds, ampicillin trihydrate and clotrimazole were prepared in DMSO at concentration of $1600 \mu \mathrm{g} / \mathrm{ml}$. The twofold dilution of the compounds were prepared $(800, \quad 400, \ldots . .6 .25$ $\mu \mathrm{g} / \mathrm{ml})$. The microorganism suspensions at $10^{6} \mathrm{CFU} / \mathrm{ml}$ (Colony Forming Unit/ml) concentration were inoculated to the corresponding wells. Plates were incubated at $36^{\circ} \mathrm{C}$ for 24 hrs to $48 \mathrm{hrs}$. The incubation chamber was kept sufficiently humid. At the end of the incubation period, the minimal inhibitory concentrations (MICs) were determined. MICs were recorded as the minimum concentration of a compound that visually inhibits the growth of tested microorganisms.

\section{Pharmacology}

\section{Chemicals and instruments}

The following chemicals were used: Celecoxib was provided from EIPICO, Egyptian International Pharmaceutical Industries Co, Egypt. Indomethacin was purchased from Nile Co. (Nile Co., for Drugs and Chem. Industries, Cairo, Egypt). 
Carrageenin, used to induce edema, was purchased from Sigma Chemicals Co. Digital plethysmometer LE7500 (Panlab S.L., Cornella, Barcelona, Spain) was used to measure the volume of paw edema., St. Louis, USA.

Computer program "Prism" was used for carrying statistical analyses. Values of $\mathrm{P}<0.05 \quad$ (significant difference) or $\mathrm{P}<0.01$ (highly significant difference) were used as the limit for statistical significance.

\section{Anti-inflammatory activity}

Anti-inflammatory activity of the compounds under investigation was studied in rats using carrageenan. A suspension of the tested compounds, and reference drug, celecoxib, in CMC $(0.5 \%$ w/v in water $)$ was administrated orally to adult male albino rats weighing (100-120 g) in dose level $\left(2.5 \times \quad 10^{-5} \mathrm{~mol} / \mathrm{kg}\right)$. Control animals were similarly treated with CMC ( $0.5 \%$ w/v in water).

After 30 minutes $0.1 \mathrm{ml}$ of freshly prepared carrageenan solution (1\% in normal saline) was injected into the subplanar region of the right hind paw according to the method of Hernandez-Perez et al. $^{20}$ The right paw volume was measured by digital plethysmometer at 1,2,3 hrs intervals after administration of the tested compounds.

The difference between the thicknesses of the two paw (right and left) was taken as a measure of edema $^{21}$.

\section{Gastric ulcerogenic effect ${ }^{22}$}

Adult male albino rats (120-200 g) were divided into 3 groups; each of six animals. Animals were starved for $24 \mathrm{hrs}$ before the experiment but had free access to water. The animals were then treated orally by means of a stomach tube with suspensions of the tested compounds and the reference drug in aqueous solution of carboxymethyl cellulose, CMC, $(0.5 \% \mathrm{w} / \mathrm{v})$ at dose levels of 10,50 , $100 \mathrm{mg} / \mathrm{kg}$. Control animals were treated with an equal volume of $0.5 \%$ carboxymethyl cellulose. After 6 hrs, the rats were sacrificed and the stomachs were removed, dissected along the greater curvature and washed with water. The lesions in gastric mucosa were determined by using stereoscopic microscope.

Ulcer was defined as at least one lesion that was $0.5 \mathrm{~mm}$ or more in length. Lesion size (mm) was measured along its greatest length and in the case of patches; five such lesions were considered the equivalent of a $1 \mathrm{~mm}$ ulcer. The sum of the lesions' lengths in each group of animals was divided by their number and expressed as the gastric ulcer index.

\section{Acute toxicity $\left(\mathrm{LD}_{50}\right)^{23}$}

Groups of adult male albino mice, each of six animals (25-30 g) were injected intraperitoneally with graded doses of the tested compounds and the reference drug. The percentage of mortality, in each group of animals, was determined $24 \mathrm{hrs}$ after the injection. Calculation of the $\mathrm{LD}_{50}$ was processed by graphical method. 


\section{Molecular docking}

All the molecular modeling studies were carried out on Intel Pentium 1.6GHZ processor, $512 \mathrm{MB}$ memory with Windows XP operating system using Molecular Operating Environment (MOE 2007-09 Chemical Computing Group, Canada $^{24}$ as the computational software. All the minimizations were performed with MOE untila RMSD gradient of $0.05 \mathrm{kcal}$ and $\mathrm{A}^{-1}$ with MMFF94X force-field and the partial charges were automatically calculated.

The X-ray crystallographic structure of murine COX-2 complexed with celecoxib (PDBID:6COX) was obtained from protein data bank. The enzyme was prepared for docking studies where (i) Ligand molecule was removed from the enzyme active site. (ii) Hydrogen atoms were added to the structure with their standard geometry. (iii) MOE Alpha Site Finder was used for the active sites search in enzyme structure and dummy atoms were created from the obtained alpha spheres.(iv)The obtained model was then used in predicting the ligandenzyme interactions at the active site.

\section{RESULTS AND DISCUSSION}

\section{Chemistry}

The synthetic reactions used for the synthesis of compounds 6a-1 are outlined in scheme 1.

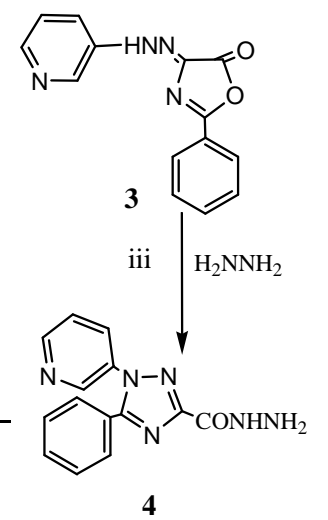<smiles>N#[N+]c1cccnc1N1COC(=O)C1</smiles>

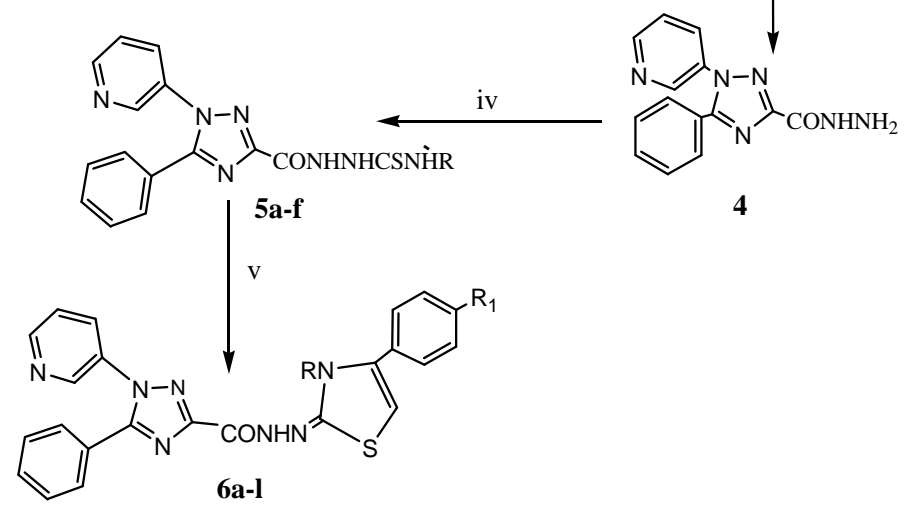

(i) $\mathrm{Ac}_{2} \mathrm{O} / \triangle$ (ii) $\mathrm{NaOAc}$

(iii) $\mathrm{CH}_{3} \mathrm{OH}$ (iv) $\mathrm{R}-\mathrm{NCS} / \mathrm{C}_{2} \mathrm{H}_{5} \mathrm{OH}$ (v) $\mathrm{Ph}(p$ - $\mathrm{ClPh}) \mathrm{COCH}_{2} \mathrm{Br} /$ fused $\mathrm{NaOAc} / \mathrm{C}_{2} \mathrm{H}_{5} \mathrm{OH}$

R: $\mathrm{CH}_{3} ; \mathrm{C}_{2} \mathrm{H}_{5} ; \mathrm{C}_{6} \mathrm{H}_{5} ; \mathrm{C}_{6} \mathrm{H}_{4} \mathrm{CH}_{3}(p) ; \mathrm{C}_{6} \mathrm{H}_{4} \mathrm{Br}(p) ; \mathrm{C}_{6} \mathrm{H}_{11}$ $\mathrm{R}_{1}=\mathrm{H}, \mathrm{Cl}$

Scheme 1: Synthesis of the target compounds 6a-l. 
Reaction of hydrazide $\mathbf{4}$ with alkyl, arylisothiocyanate in ethanol yielded the corresponding thiosemicarbazide derivatives 5a-f. Condensation of compounds 5a-f with appropriate phenacyl bromide in boiling ethanol containing anhydrous sodium acetate lead to the formation of compounds $\mathbf{6 a - 1}$ as one product as confirmed by TLC.

The chemical structures of the reaction products were confirmed by elemental analyses, IR, ${ }^{1} \mathrm{H}-\mathrm{NMR},{ }^{13} \mathrm{C}$ NMR and MS. IR spectra showed the appearance of characteristic absorption bands at 3410, 1678-1634, $1613-1610 \mathrm{~cm}^{-1}$ assigned to $\mathrm{NH}, \mathrm{CO}$ and $\mathrm{CN}$, respectively.

${ }^{1} \mathrm{H}-\mathrm{NMR}$ spectra lacked the signals which appeared at (9.6010.10) corresponding to reported signals of $\mathrm{NHCS}^{14}$ and showed a new singlet signal at $\delta$ 6.90-6.25 integrated for one proton attributed to the $\mathrm{C} 5-\mathrm{H}$ of the thiazoline ring, in addition to increase number of aromatic protons. Mass spectra (ESIMS) of compounds 6a-d and $6 \mathbf{l}$ showed $\mathrm{M}^{+}+1$ or $\mathrm{M}^{+}+\mathrm{Na}$ peaks, which were in agreement with their molecular formula.

\section{Antimicrobial activity}

Compounds 6a-l were tested for their in-vitro antimicrobial activity against Escherichia coli (E. coli) ATCC 25922, Staphylococcus aureus (S. aureus) ATCC 19433, and Candidia albicans (C. albicans) by the method shown in the experimental part. $^{19}$ Ampicillin trihydrate and clotrimazole were used as standard antibacterial and antifungal agents, respectively. Some of the tested compounds showed significant antibacterial and antifungal activities when compared with reference drugs.

The MIC values are generally within the range of $12.5-200 \mathrm{~g} / \mathrm{mL}$ against evaluated strains. In comparing their MIC values with ampicillin, it was found that compound 6i showed a similar level of activity against Staphylococcus aureus while the compounds $\mathbf{6 b}, \mathbf{6 h}$ possessed one fourth the activity of ampicillin. Compounds $\mathbf{6 j}$ and $\mathbf{6 l}$ exhibited similar activity against Escherichia coli, also the rest of compounds revealed activity ranging from one fourth to one eighth activity of ampicillin. Substitution at positions 3 and 4 of thiazoline nucleus with halogenated phenyl rings may increase the antibacterial activity. All compounds were less active against Candida albicans when compared with clotrimazole as shown in Table 2.

\section{Anti-inflammatory activity}

The preliminary anti-inflammatory activity of the synthesized compounds was evaluated against carrageenaninduced rat paw edema using the method by Hernandez-Perez et al. ${ }^{20}$ The compounds were tested at $2.5 \times 10^{-5} \mathrm{~mol} / \mathrm{kg}$ oral dose and compared with celecoxib as reference drug. The results are listed in Table 3. The histograms, Figures (1\&2) showed the per cent inhibition of edema induced by reference drug and tested compounds. 
Table 2: Minimal inhibitory concentration (MIC $\mu \mathrm{g} / \mathrm{ml}$ ) of tested compounds.

\begin{tabular}{|c|c|c|c|}
\hline Compd. No. & E. coli & S. aureus & C. albicans \\
\hline $\mathbf{6 a}$ & 100 & 100 & $>200$ \\
\hline $\mathbf{6 b}$ & 200 & 50 & $>200$ \\
\hline $\mathbf{6 c}$ & 100 & 100 & $>200$ \\
\hline $\mathbf{6 d}$ & 100 & 100 & $>200$ \\
\hline $\mathbf{6 e}$ & 100 & 100 & $>200$ \\
\hline $\mathbf{6 f}$ & 200 & 100 & $>200$ \\
\hline $\mathbf{6 g}$ & 100 & $>200$ & $>200$ \\
\hline $\mathbf{6 h}$ & 100 & 50 & $>200$ \\
\hline $\mathbf{6 i}$ & 100 & 12.5 & 200 \\
\hline $\mathbf{6 j}$ & 25 & $>200$ & $>200$ \\
\hline $\mathbf{6 k}$ & 100 & $>200$ & $>200$ \\
\hline $\mathbf{6 l}$ & 25 & $>200$ & $>200$ \\
\hline Ampicillin & 25 & 12.5 & --- \\
\hline Clotrimazole & -- & -- & 12.5 \\
\hline
\end{tabular}

Table 3: Anti-inflammatory activity of target compounds $6 \mathbf{6}-\mathbf{l}$ at $2.5 \times 10^{-5} \mathrm{~mol} / \mathrm{kg}$ dose level.

\begin{tabular}{|c|c|c|c|}
\hline \multirow[t]{2}{*}{ Compound } & \multicolumn{3}{|c|}{$\begin{array}{l}\text { Anti-inflammmatory activity } \\
\% \text { inhibition } \pm \text { S.E } E^{(a, b)}\end{array}$} \\
\hline & $1 \mathrm{hr}$ & $2 \mathrm{hrs}$ & $3 \mathrm{hrs}$ \\
\hline Control & 0.00 & 0.00 & 0.00 \\
\hline Celecoxib & $54.2 \pm 1.56^{* *}$ & $68.6 \pm 1.43^{* *}$ & $76.4 \pm 1.18 * *$ \\
\hline $6 a$ & $38.0 \pm 2.21 * *$ & $41.2 \pm 1.8 * *$ & $46.3 \pm 2.51 * *$ \\
\hline $6 \mathbf{b b}$ & $43.0 \pm 2.63 * *$ & $47.2 \pm 2.08 * *$ & $52.2 \pm 1.44 * *$ \\
\hline $6 c$ & $46.3 \pm 2.45 * *$ & $50.3 \pm 3.18 *$ & $55.2 \pm 3.12 * *$ \\
\hline 6d & $65.4 \pm 2.12^{* *}$ & $72.0 \pm 1.56^{* *}$ & $79.1 \pm 1.80 * *$ \\
\hline $6 e$ & $38.5 \pm 3.50 * *$ & $46.4 \pm 1.80 * *$ & $48.0 \pm 2.45^{*}$ \\
\hline 6f & $41.5 \pm 2.25^{*}$ & $48.1 \pm 6.3 * *$ & $49.9 \pm 2.23 * *$ \\
\hline $6 g$ & $23.6 \pm 5.56^{*}$ & $29.5 \pm 6.11 * *$ & $36.9 \pm 5.24 * *$ \\
\hline $6 h$ & $25.3 \pm 4.96^{*}$ & $31.1 \pm 1.45^{* *}$ & $38.5 \pm 2.90^{*}$ \\
\hline $6 \mathbf{6}$ & $40.4 \pm 3.52 * *$ & $44.1 \pm 3.56^{* *}$ & $48.0 \pm 3.18^{* *}$ \\
\hline $6 \mathbf{j}$ & $41.3 \pm 1.88 * *$ & $47.2 \pm 2.08 * *$ & $51.6 \pm 3.04^{*}$ \\
\hline $6 \mathbf{k}$ & $42.6 \pm 1.35 * *$ & $48.0 \pm 2.35 * *$ & $51.7 \pm 1.15^{* *}$ \\
\hline 61 & $55.2 \pm 1.72 * *$ & $68.6 \pm 1.83^{* *}$ & $77.5 \pm 1.56^{* *}$ \\
\hline
\end{tabular}

${ }^{\text {a }}$ S.E: standard error

${ }^{b *}$ Significant difference at $\mathrm{P}<0.05 ; * *$ Significant difference at $\mathrm{P}<0.01$. 


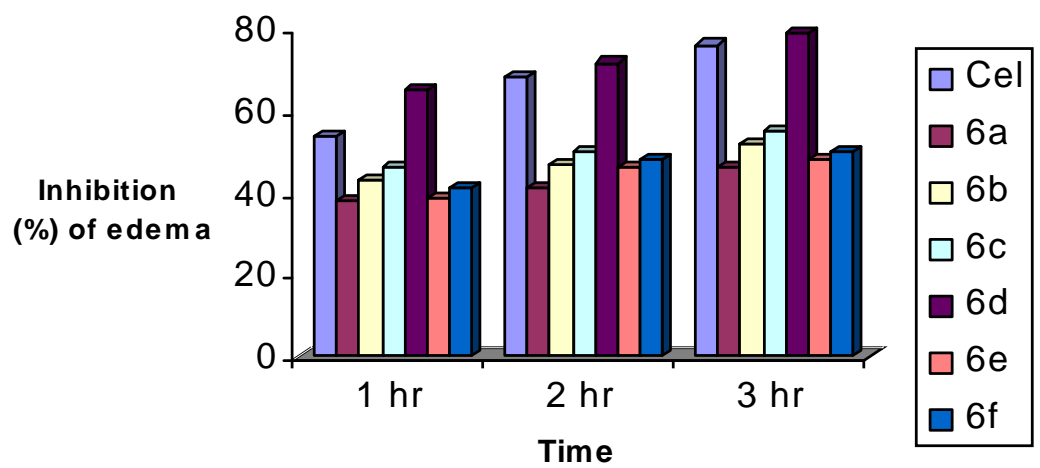

Fig. 1: Inhibition (\%) of carrageenan- induced rat paw edema by Celecoxib $(\mathrm{Cel})$, and tested compounds $\mathbf{6 a - 6 f}$ in treated groups of rats at $2.5 \times 10^{-5}$ $\mathrm{mol} / \mathrm{kg}$

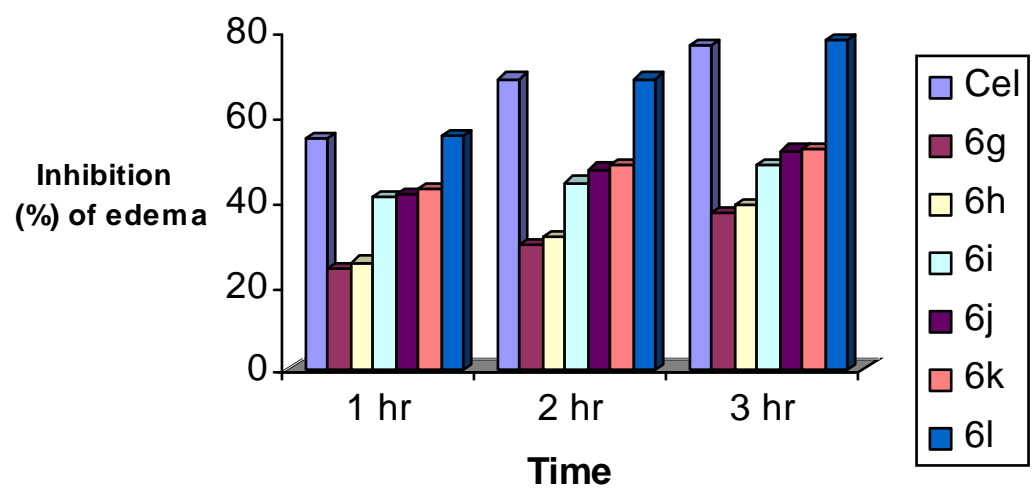

Fig. 2: Inhibition (\%) of carrageenan- induced rat paw edema by Celecoxib $(\mathrm{Cel})$, and tested compounds $\mathbf{6 g}-6 \mathbf{1}$ in treated groups of rats at $2.5 \times 10^{-5}$ $\mathrm{mol} / \mathrm{kg}$.

Results showed that most of the tested compounds exhibited significant $\quad(\mathrm{P}<0.05) \quad$ inhibition against carrageenan-induced rat paw edema with inhibition per cent (36.9$97.1 \%)$ relative to celecoxib. Among these derivatives, compounds $\mathbf{6 d}$ and 6l showed maximum inhibition of inflammation $(79.1 \%, 77.5 \%)$ and were found to be more potent than celecoxib $(76.4 \%)$. While derivatives $\mathbf{6 g}$ and $6 \mathbf{h}$ were the least active compounds. From the biological activity studies we concluded that (i) substitution at position 4 of thiazoline ring with $p$-chlorophenyl increases 
activity more than unsubstituted phenyl, (ii) the order of decreasing activity is as follows; ethyl > cyclohexyl $>\mathrm{CH}_{3}>p$-Br-phenyl > phenyl $>p-\mathrm{CH}_{3}$-phenyl.

In the previous study, the order of decreasing in anti-inflammatory activity of thiosemicarbazides 5a-f is as follows $p$ - $\mathrm{Br}$-phenyl $>p-\mathrm{CH}_{3}-$ phenyl > phenyl > cyclohexyl > ethyl $>\mathrm{CH}_{3}{ }^{14}$.

\section{Gastric ulceration $^{22}$}

The compounds $\mathbf{6 d}$ and $\mathbf{6} \mathbf{1}$ were screened for their ulcerogenic activity at dose level 10, 50, $100 \mathrm{mg} / \mathrm{kg}$. Results indicated that compounds $\mathbf{6 d}$ and $\mathbf{6 l}$ did not induce any ulcerogenic effect at $10 \mathrm{mg} / \mathrm{kg}$ dose. At higher doses, the tested compounds exhibited low gastric ulcerogenicity compared with indomethacin, which caused severe ulceration at all dose levels, Table 4.

\section{Acute toxicity $\left(\mathbf{L D}_{\mathbf{5 0}}\right)$}

The acute toxicity of the most active compounds; 6d and $\mathbf{6} \mathbf{1}$ was determined by calculating their $\mathrm{LD}_{50}$ values using graphical method ${ }^{23}$. The $\mathrm{LD}_{50}$ of compounds $\mathbf{6 d}$ and $\mathbf{6} \mathbf{1}$ was found to be 100 and $90 \mathrm{mg} / \mathrm{kg}$ (i.p.), respectively, while $L_{50}$ of indomethacin was found to be 50 $\mathrm{mg} / \mathrm{kg} \quad$ (i.p.). In conclusion compounds 6d and $\mathbf{6 l}$ showed significant anti-inflammatory activity without ulcerogenic toxicity.

\section{Molecular modeling study}

Molecular dockings of compounds 5 a-f, 6a-l were performed in order to rationalize the obtained biological results, Besides, molecular docking studies verfied understanding the various interactions between the ligands and enzyme active site in detail. Docking studies of the inhibitors were performed by MOE

Table 4: Ulcerogenic effects of compounds $\mathbf{6 d}$ and $\mathbf{6}$ in comparison to indomethacin.

\begin{tabular}{|c|c|c|c|}
\hline Compound & Dose $\mathrm{mg} / \mathrm{kg}$ & $\begin{array}{c}\text { Ratio of ulcerated } \\
\text { animals }\end{array}$ & $\begin{array}{c}\text { Ulcer index } \\
\text { (mean } \pm \text { S.E. })\end{array}$ \\
\hline \multirow{3}{*}{ Indomethacin } & 10 & $3 / 6$ & $\left(1.35^{* *} \pm 0.18\right)$ \\
\cline { 2 - 4 } & 50 & $5 / 6$ & $\left(1.88^{* *} \pm 0.15\right)$ \\
\cline { 2 - 4 } & 100 & $6 / 6$ & $\left(2.10^{* *} \pm 0.17\right)$ \\
\hline \multirow{3}{*}{$6 \mathrm{~d}$} & 10 & $0 / 6$ & 0.00 \\
\cline { 2 - 4 } & 50 & $0 / 6$ & 0.00 \\
\cline { 2 - 4 } & 100 & $1 / 6$ & $(0.50 \pm 0.1)$ \\
\hline \multirow{3}{*}{61} & 10 & $0 / 6$ & 0.00 \\
\cline { 2 - 4 } & 50 & $1 / 6$ & $(0.50 \pm 0.1)$ \\
\cline { 2 - 4 } & 100 & $1 / 6$ & $\left(0.75^{*} \pm 0.12\right)$ \\
\hline
\end{tabular}

*Significant difference at $\mathrm{P}<0.05 ; *$ Significant difference at $\mathrm{P}<0.01$. 
(Molecular Operating Environment) using murine COX-2 co-crystallized celecoxib (PDBID:6COX) as a template. We performed 100 docking interactions for each ligand and the top-scoring configuration of each of the ligand-enzyme complexes was selected on energetic grounds.

Docking of compound 6d, (Figs. $3 \& 4)$, showed that the ligand was oriented so that the moiety $\mathrm{CONHN=}$ was in the vicinity of His 90 residue forming an ionic interaction with both carbonyl group $\left(\right.$ distance $\left.=2.68 \mathrm{~A}^{\circ}\right)$ and $-\mathrm{N}=\left(\right.$ distance $\left.=2.71 \mathrm{~A}^{\circ}\right)$, a hydrogen bond interaction between the NH and Leu 352 (distance $=2.14$ $\mathrm{A}^{\circ}$ ).
The pyridine, phenyl and triazole rings were located in a hydrophobic pocket surrounded by Phe 518, Ala 527, Val 523, Gly 526, Gly 354 and Met 522. Also thiazoline, $p$-Cl-phenyl rings were surrounded by His 90 , Ser 353, Gln192, Arg 513, His 351 and Asp 515. This arrangement is also common to most derivatives 6a-l with small differences in ionic interaction or hydrophobic pocket. On the other hand, docking of the corresponding thiosemicarbazide compound $\mathbf{5 b}$ showed that the ligand was oriented so that the moiety CONHNH was in the vicinity of His 90 residue forming an ionic interaction with the carbonyl

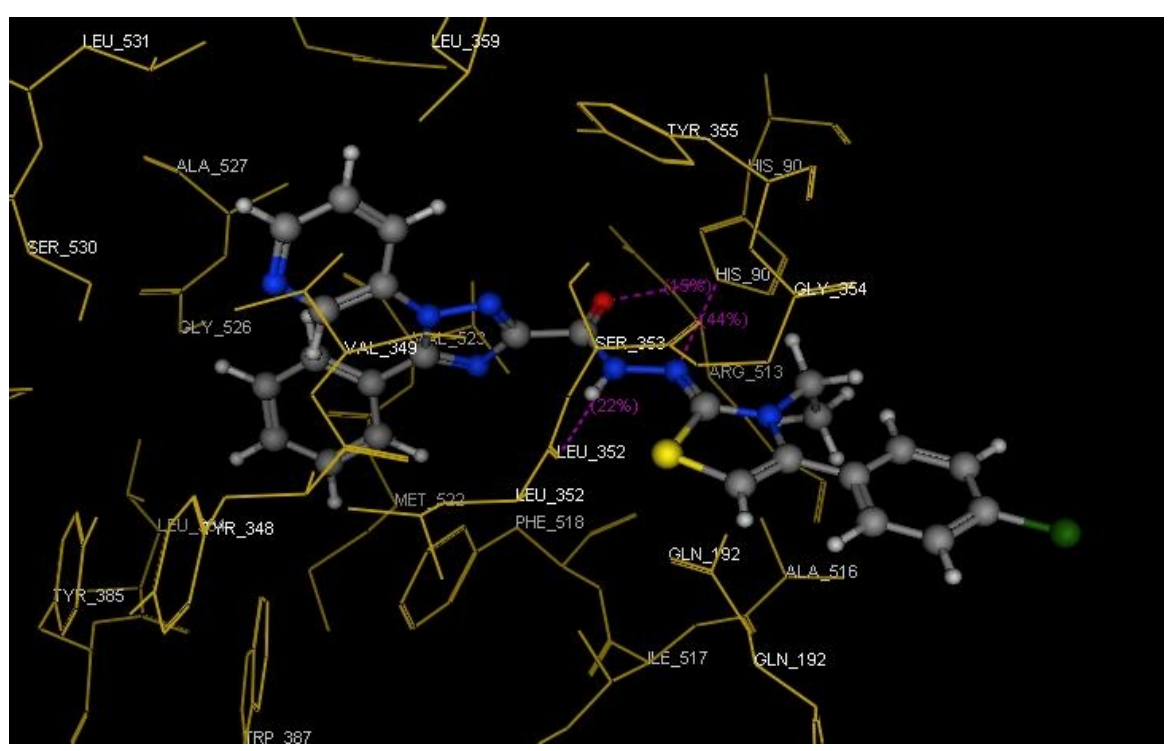

Fig. 3: 3D docked structure of $\mathbf{6 d}$ (ball and stick) at COX-2 active site. 


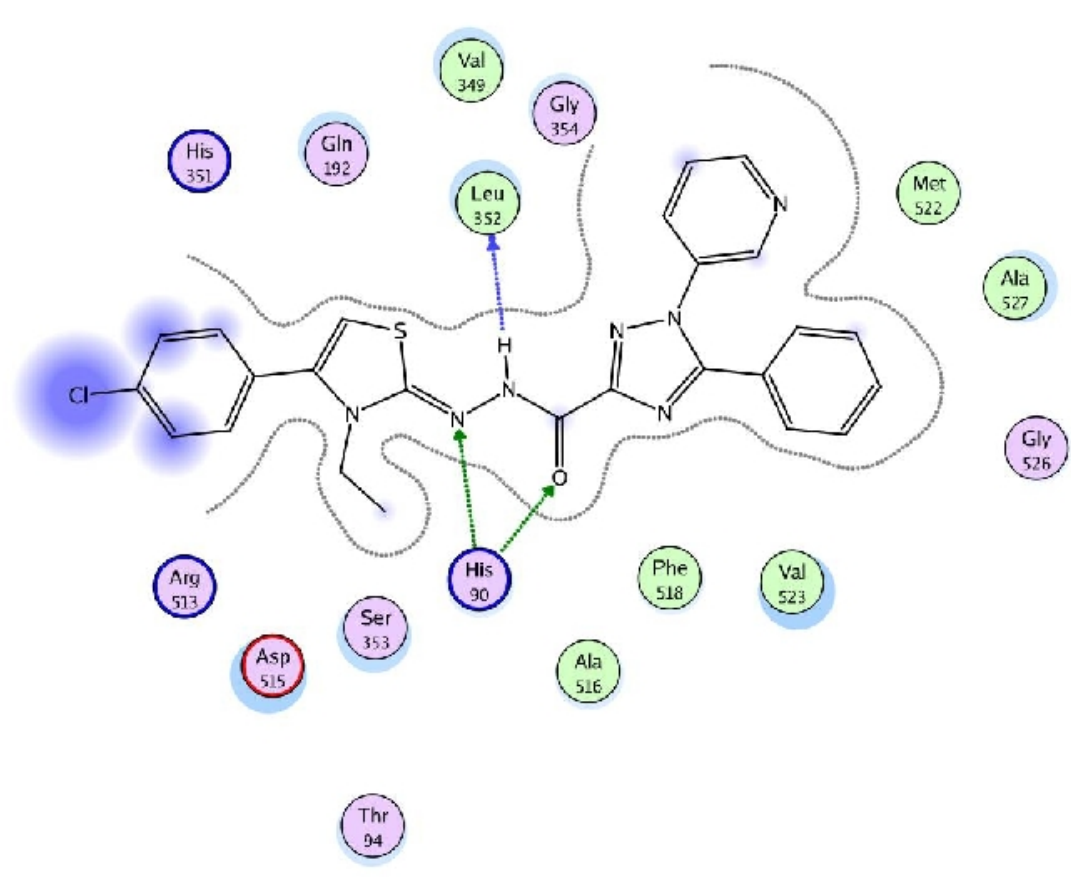

Fig. 4: Simplified structure of $\mathbf{6 d}$ docked at COX-2 active site.

group $\left(\right.$ distance $\left.=1.77 \quad \mathrm{~A}^{\circ}\right), \quad \mathrm{a}$ hydrogen bond interaction between the $\mathrm{NH}$ and Leu 352 (distance $=1.73$ $\left.\mathrm{A}^{\circ}\right)$. This means similar contacts as 6d with one missing feature, which in accordance with the antiinflammatory activity. Docking of compound $\mathbf{6}$ showed a hydrogen bond interaction between His 90 and both of the carbonyl (distance $=2 . .69$ $\mathrm{A}^{\circ}$ ), and $-\mathrm{N}=$ group $($ distance $=2.70$ $\mathrm{A}^{\circ}$ ). A hydrogen bond interaction between the $\mathrm{NH}$ and Leu 352 $\left(\right.$ distance $\left.=2.34 \mathrm{~A}^{\circ}\right)$. Docking of the corresponding thiosemicarbazide $\mathbf{5 c}$ showed ionic interaction between carbonyl and His 90 (distance $=2.45$ $\mathrm{A}^{\circ}$ ) and NHCS and Ser 353 (distance $=1.88 \mathrm{~A}^{\circ}$ ). Number of hydrogen bond is less than that of the corresponding cyclized form which in accordance with the antiinflammatory activity.

On the contrary docking study of thiosemicarbazide compound $\mathbf{5 f}$ showed an increased by one feature than that of the corresponding cyclized compound $\mathbf{6 j}$. The results indicated that compound $\mathbf{5 f}$ showed an ionic interaction between His 90 and both carbonyl and $\mathrm{NH}$ (distance = 2.14, $2.24 \mathrm{~A}^{\circ}$ ) and NHCS with Ser 
353 (distance $=2.18 \mathrm{~A}^{\circ}$ ), while docking of $\mathbf{6 j}$ showed an ionic interaction between His 90 and both carbonyl and $\mathrm{NH}$ (distance $=2.78$, $2.40 \mathrm{~A}^{\circ}$ ), which in accordance with anti-inflammatory activity. This means that there is relation between ionic interaction with the receptor and anti-inflammatory activity.

From the above mentioned data, the molecular modeling studies of the examined compounds showed that they bound to the COX-2 active site with position and orientation very close to that resulting from the crystal structure of celecoxib complex with COX-2 (a hydrogen bond with His 90 $\left(2.91 \mathrm{~A}^{\circ}\right)$, Leu $352\left(2.28 \mathrm{~A}^{\circ}\right)$, Ser 352 $\left(1.58 \mathrm{~A}^{\circ}\right)$.

\section{Conclusion}

We reported here the synthesis of 1,2,4-triazole carbohydrazide derivatives. The synthesized compounds were tested for their antimicrobial and anti-inflammatory activity.Compound 6i was the most active one against Staphylococcus aureus, while compounds $\mathbf{6 j}$ and $\mathbf{6 l}$ showed moderate activity against Escherichia coli. Most of the tested compounds exhibited significant antiinflammatory activity in the carrageenan-induced rat paw edema test, with low gastric ulcerogenicity compared with indomethacin. The molecular modeling studies suggested that compounds $\mathbf{6 d}, \mathbf{6 l}$ exhibited higher affinity for COX-2 active site and hence increased antiinflammatory activity than the other derivatives.

\section{REFERENCES}

1- K. C. Ragenovic, V. Dimova and A. Buzarovska, Molecule, 6, 815 (2001).

2- S. Demirayak, K. Benkli and K. Guven, Eur. J. Med. Chem., 35, 1037 (2000).

3- F. P. Invidiata and G. Fuurno, ibid., 35, 715 (2000).

4- A. Tasaka, N. Tamura, Y. Matsushita, K. Teranishi, R. Hayashi, K. Okongi and K. Itoh, Chem. Pharm. Bull., 41, 1035 (1993).

5- R. K. Mali, R. R. Somani, M. P. Toraskari, K. K. Mali, P. P. Naik and P. Y. Shirodkar, Inter. J. Chem. Tech. Res., 1, 168 (2009).

6- L. Meerpoel, L. Backx, L. Veken, J. Heeres, D. Corens, A. Groot, F. Odds, F. Gerven, F. Woestenborghs, A. Breda, M. Oris, P. Dorsselaer, G. Willemsens, K. Vermuyten, P. Marichal, H. Bossche, J. Ausma and M. Borgers, J. Med. Chem. 48, 2184 (2005).

7- I. A. Shehata, Saudi Pharm. J., 11, 87 (2003).

8- H. Y. Hassan, A. A. El-Shorbagi, N. A. El-Koussi and A. O. Abdel-Zaher, Bull. Pharm. Sci., Assiut University, 17, 27 (1994).

9- K. Sung and A. R. Lee, J. Heterocycl. Chem., 29, 1101 (1992).

10- M. D. Mullican, M. W. Wilson, D. T. Connor, C. R. kostlan, D. J. Schrier and R. D. Dyer, J. Med. Chem., 36, 1090 (1993). 
11- D. H. Boschelli, D. T. Connor, D. A. Bornemeier, R. D. Dyer, J. A. Kennedy, P. J. kuipers, G. C. Okonkwo, D. J. Schrier and C. D. Wright, ibid., 36, 1802 (1993).

12- L. Czollner, G. Szilagyi, J. Lango and J. Jamky, Arch. Pharm. (Weinheim), 323, 225 (1990).

13- E. Palaska, G. Sahin, P. Kelicen, N.T. Durlu and G. Altinok, IL Farmaco, 57, 101 (2002).

14- S. Rabea, N. A. El-Koussi, H. Y. Hassan and T. A. El-Fadel, Arch. Pharm. Chem. Life Sci., 339, 32 (2006).

15- G. Turan-Zitouni, Z. A. Kaplancikli, A. Ozdemir, P. Chevallet, H. B. Kandilci and B. Guümüsel, ibid., 340, 586 (2007).

16- B. Tozkoparan, E. Küpeli, E.Yesilada and M. Ertan, J. Bioorg. Med. Chem., 15, 1808 (2007).

17- A. M. Abdel-Megeed, H. M. Abdel-Rahman, G. S. Alkaramany and M. A. ElGendy, Eur. J. Med. Chem., 44, 117 (2009).
18- J. R. Van, Nature (London), New Biol., 231, 232 (1971).

19- B. Henderson, in: Dale M. M.; Foreman J. C. and Fan T-P. D. (eds): "Textbook of Immunopharmacology", $3^{\text {rd }}$ ed.,Blackwell Scientific Publications, London, 1994 pp. 16, 193.

20- M. Hernandez-Perez, R. M. Rabanal, M. C. de la Torre and B. Rodriguez, Planta Med., 61, 505 (1995).

21- H. Nojima, H. Tsuneki, I. Kimura and M. Kimura, Br. J. Pharmacol., 116, 1680 (1995).

22- H. Ikuta, H. Shirota, S. Kobayashi, Y. Yamagishi, K. Yamada, I. Yamatsu and $\mathrm{K}$. Katayama, J. Med. Chem., 30, 1995 (1987).

23- A. A. Bekhit and H. T. Fahmy, Arch. Pharm. Pharm. Med. Chem., 336, 111 (2003).

24- Molecular Operating Environment (MOE), Version 2007.09, Chemical Computing Group, Inc., Montreal, Quebec, Canada, 2005. http://www. Chemcomp. Com>. 